Vol. 2, No. 2, 2021

Taras Postranskyy, Mykola Boikiv

Lviv Polytechnic National University

12, Bandery Str., Lviv, 79000, Ukraine

(C) T. Postranskyy, M. Boikiv, 2021

https://doi.org/10.23939/tt2021.02.020

\title{
AN INFLUENCE OF MOUNTAINOUS TRAFFIC CONDITIONS ON THE FUNCTIONAL STATE OF A BUS DRIVER
}

Summary. Ensuring the transport process requires proper interaction of all parts of the system "driver - car - road - environment" and its subsystems. In this case, the driver is often a "weak" component of the system, and his actions can reduce the level of road users' safety. It should be noted that the reliability of the driver can be considered as the probability of his troublefree and error-free operation, as well as the proper level of his regulatory mechanisms functioning. In this case, to analyze the activities and readiness of the driver for his professional activities, indicators of functional status are often used. Thus, the study of the "human factor" in the transport process is an important task to ensure the reliability of the whole transport system.

Today the most of all transportation is carried out by road. The timeliness and safety of cargo delivery and passenger safety depend on the driver's actions. At the same time, the driver is influenced by a considerable number of external environmental factors during his work. One of the most important factors is the mountainous traffic conditions, which often have many changes in plan and the profile of roads. Another feature of such traffic conditions is the height above sea level, affecting the human body, particularly its functional state.

Considering the above, the paper measures the heart rate variability of bus drivers moving on a route that was partly in the mountain's conditions. During the research, video recording and registration of the vehicle's geolocation were also carried out. This made it possible to establish indicators of the driver's functional state in specific periods. After processing the obtained values, the influence of mountainous traffic conditions on the bus drivers 'indicator of regulatory systems' activity was established.

Key words: functional state, driver, bus, mountainous traffic conditions, traffic safety, reliability of the driver, an indicator of regulatory systems' activity.

\section{INTRODUCTION}

The driver is the leading and controlling part of the "driver - car - road - environment" system. Therefore, road safety depends on his proper operation. In turn, his behavior is influenced by the functional state of his body. The functional state is often reflected in the form of indicators that carry information about the body's energy reserves. Accordingly, this indicator can be used as data on the readiness of the operator to perform his professional tasks. The concept of functional state is often used in sports medicine to identify the early stages of fatigue in athletes and their functionality. However, scientists consider the functional state as an indicator of a person's mental state. This is since different mental states of the human body are a phenomenon that reflects its interaction with the environment, which is represented at some point by a specific situation [1-3].

In transport studies, functional status can be considered as a factor influencing driver behavior and, consequently, the likelihood of a traffic accident. In this case, this indicator may reflect the effective side 
of the driver's activity. Accordingly, studying the human factor in the system "driver - car - road environment" $[2,4]$ is becoming increasingly necessary.

\section{RESEARCH STATEMENT}

The article aims to identify changes in the bus driver's functional state whose route runs through mountainous traffic conditions. To achieve this, the following tasks are accomplished:

- to analyze methods of the driver's functional state research and to choose the corresponding necessary equipment;

- to analyze the altitude values of the road through which the bus's route runs;

- to carry out full-scale measurements of the driver's heart rate variability and video recording of conditions in which the bus moves;

- to analyze the data obtained and to establish the dynamics of changes in the bus driver's functional state moving on roads in mountainous conditions and beyond.

\section{TRAFFIC CONDITIONS AND THEIR IMPACT ON THE RELIABILITY OF THE DRIVER}

Researchers have repeatedly noted that the parameters of the driver's activity largely depend on his functional state. Therefore, during transport research of this type, special attention is often paid to the person (driver), who uses the appropriate equipment and has the efficiency and reliability of activities in a specific environment. This indicator can also be displayed as a traffic safety indicator. In this case, quantitatively, it is often reflected in the following values [5]:

- operating time;

- operating time for failure;

- total operating time.

When considering the probabilistic indicators of the drivers` work reliability, they are often reflected as follows [5]:

- the probability of trouble-free operation;

- probability of failures;

- the intensity of work.

Also, scientists reflect the reliability of the driver's work in the form of the ability to control the vehicle without error during the entire period of operation in any road conditions. At the same time, the following important factors that establish the reliability of the driver should be identified, in particular: the level of efficiency, his preparedness for critical situations, and professional suitability. Accordingly, the study of these indicators and their constant monitoring will increase road safety [6].

Other studies on the driver's reliability indicate the relationship of this indicator with the quantitative characteristics of his cardiovascular system functionality. The following main factors often affect the infallibility of the driver [7]:

- driver`s suitability to drive a car;

- preparedness;

- efficiency.

It is known that the reliability of the driver is affected by the highway's volume-capacity ratio. As the load level increases, the driver gets tired faster, and the reliability of his work decreases. Accordingly, it is necessary to consider the parameters of traffic flows while planning the work of drivers. Thus, the reliability of the driver's work affects both the road safety of the participants in this process and the operation of the system "driver - car - road - environment" in general. At the same time, changes in the driver's reliability are often associated with changes in his functional state. This indicator is considered as an opportunity to perform specific tasks in different conditions. Also, it is established that with the change of human's functional state, the reaction time changes in different road situations, the distribution of attention between different objects of the transport process changes, the probability of erroneous actions increases, etc. [8-10]. 
Following the above, we can conclude that the functional state of the driver is an essential indicator of his work reliability and can be used as an indicator of the system's "driver - car - road - environment" failure probability. Thus, the study of psychophysiological indicators of the driver and their impact on road safety is a topical issue today. Concerning the methods of studying the driver's functional state, today in transport research often use the following [11]:

- electrocardiogram (ECG);

- electroencephalogram;

- electrooculogram;

- skin galvanic reaction.

The choice of research method often depends on the conditions in which the measurements will be made, the available equipment, and the measurements' duration. However, the most popular of these is ECG recording. They are obtained by recording the changes in electrical potentials that occur due to the excitation of the heart muscle. In this case, the indicator obtained from the ECG recording, which is most often used in transport studies, is heart rate variability (HRV). This indicator reflects the adaptation of the organism to environmental conditions and external factors [12]. The calculation of this indicator is based on the analysis of R-R intervals of ECG recording (Fig. 1).

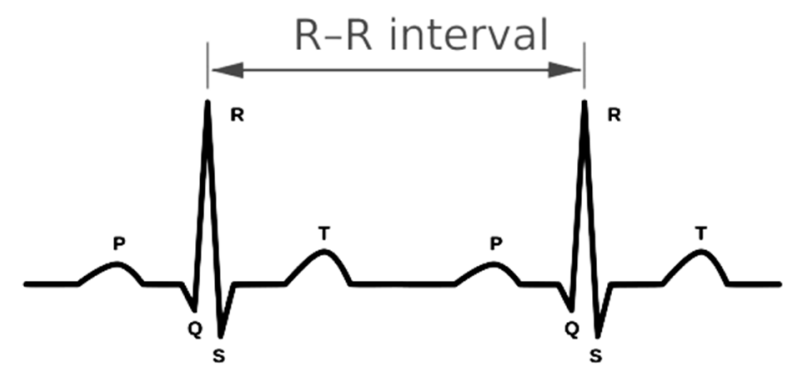

Fig. 1. R-R intervals in the fragment of the ECG recording

Today, various indicators are used which can reflect the functional state of the driver. One of these is the indicator of regulatory systems' activity created by R.M. Baevsky [13]. The input data for the calculation of this indicator are the following values of HRV:

- mathematical expectation $(\mathrm{M}, \mathrm{rNN})$ - an indicator that reflects the final result of the impact on the cardiovascular system as a whole;

- standard deviation $(\delta, \mathrm{SDNN})$ - one of the main indicators of HRV, which characterizes the state of regulatory mechanisms;

- mode (Mo) - an indicator that reflects the number of R-R intervals that are most common;

- variational range $(\mathrm{BP}, \mathrm{dX})$ - reflects the difference between the largest and smallest values of $\mathrm{R}$ $\mathrm{R}$ intervals;

- mode amplitude (AMo) - reflects the proportion of cardio intervals that correspond to the value of mode;

- coefficient of variation (CV) - a normalized estimate of the standard deviation;

- spectral power in the very-low-frequency range (VLF);

- spectral power in the low-frequency range (LF);

- spectral power in the high-frequency range (HF).

$$
P=|A|+|B|+|C|+|D|+|E|,
$$

where $A$ - the total effect of the regulation (expressed through changes in $\mathrm{rNN}$ ); $B$ - automation function (expressed through changes in SDNN, dX, CV); $C$ - vegetative homeostasis (expressed through changes in $\mathrm{dX}, \mathrm{AMo}, \mathrm{IH}) ; D$ - stability of regulation (expressed through a change in $\mathrm{CV}$ ); $E$ - the activity of nerve centers (expressed through changes in VLF / TF, LF / TF, HF / TF). 
Quantitative characterization of this indicator is obtained based on HRV analysis and the activity of the cardiovascular system in general. The obtained values are displayed on points from 1 to 10 and reflect the following states of the human's body [14]:

- $1,2,3$ - the state of regulatory systems within the optimal tension, which is necessary for the interaction of the human body with the environment;

- 4, 5 - moderate stress, at which the body needs additional functional reserves to adapt to environmental conditions. The state of the body is observed during adaptation at the beginning of the working day to work and emotional stress;

- 6,7 - pronounced stress of regulatory systems, which mobilizes the body's defense mechanisms;

- $8,9,10$ - the state of regulatory systems depletion, failure of adaptation. The state of the body is characterized by a decrease in the activity of regulatory mechanisms and there is accumulated fatigue and nervous tension. Protective and adaptive mechanisms of the body do not cope and can not respond to external factors.

Traffic conditions are one of the main factors influencing the functional state of the driver and, as a consequence, the reliability of his work. Different scientists divide the general conditions of motion by different criteria. However, the most common options take into account traffic and its features. Thus, all traffic conditions can be divided into the following:

- movement of the vehicle within the settlement;

- movement of the vehicle in mountains;

- movement of the vehicle in the plains terrain.

Each type of the above traffic conditions has its characteristics and certain factors influencing the driver and his activities. This is because traffic conditions can often be reflected through the transport and operational levels of roads. After all, they affect the performance of the subsystem "raffic flow - road conditions" in particular [15]:

- intensity;

- density;

- speed;

- level of traffic safety;

- road or street capacity, etc.

Traffic conditions are a significant factor influencing the functional state of the driver because their abrupt change can lead to excessive stress and untimely or erroneous decision-making by the driver. In articles $[16,17]$, the authors note that the influence of traffic conditions on the driver can be due to the following:

- elements of the street or road that have a direct impact on driving;

- weather conditions;

- vehicles moving in the forward and reverse direction;

- objects that are not related to traffic, but the driver pays attention to them.

Based on the above, it is possible to conclude the need to consider traffic conditions while studying the functional state of the driver. In particular, the factors influencing the reliability of the driver must first include the area in which the vehicle is moving. Thus according to the results of the existing researches analysis, it is established that conditions of movement in mountainous terrain carry out the greatest influence on the driver's organism during its work. Accordingly, the study of the dynamics in the driver's functional state changes in such traffic conditions is relevant and requires detailed investigation.

\section{INVESTIGATION OF THE BUS DRIVER'S FUNCTIONAL STATE IN MOUNTAINOUS TRAFFIC CONDITIONS}

To study the functional state of the driver's body, the method of ECG recording analysis was chosen, in particular, to obtain the necessary HRV indicators, which are then used to calculate the indicator of regulatory systems' activity. Polar $\mathrm{H} 7$ was selected as a device for recording the required input data 
(Fig. 2). It carries out continuous registration of HRV values only. This device has sensitive sensors and, as a consequence, performs a more accurate recording of R-R interval data. It should be noted that it is portable and placed directly on the body of the subject.

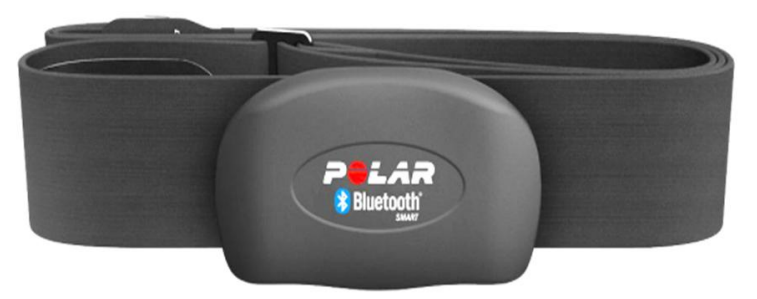

Fig. 2. Polar $H 7$ device for driver $H R V$ registration

Also, the advantages of using the Polar device include the fact that it doesn't create discomfort for the drivers during the research, and recording can be done online on a mobile device with a Bluetooth adapter. In this case, according to the scientific article [18], when studying the functional state of drivers using the Polar device, you should use the following software: HRVxt, HRV monitor, HRV lite, etc.

The study of HRV indicators was carried out passively - no influence on the driver's activity was carried out. At the same time, experimental research was previously carried out, which provided that:

- the main objectives of the study are to measure the R-R intervals of drivers who drive buses in mountainous traffic conditions;

- to establish the dynamics of changes in the indicators of the drivers' functional state in mountainous traffic conditions, it is necessary to measure similar indicators while driving in plains conditions

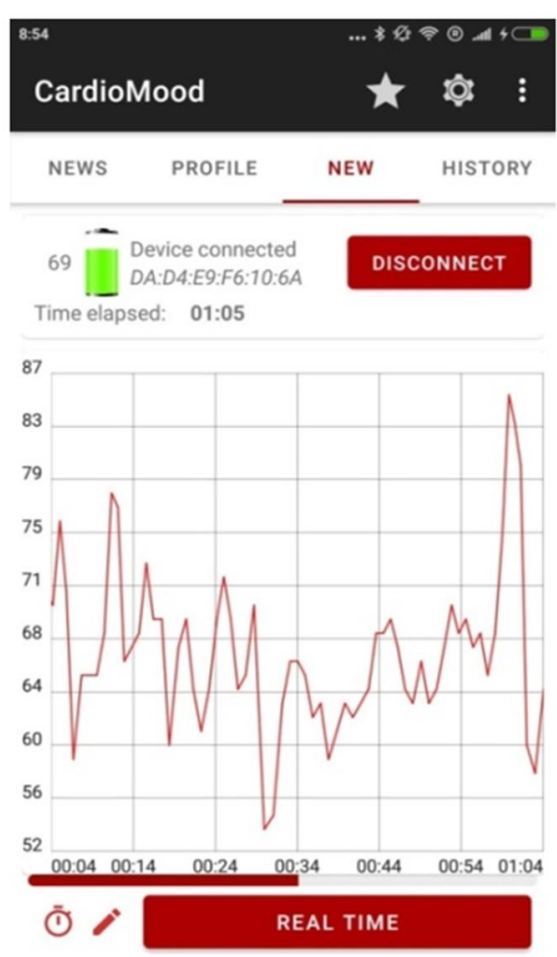

Fig. 3. CardioMood HRV lite mobile application interface
- during research, it is necessary to use the Polar H7 device and the HRV lite mobile application (Fig. 3);

- video recording and geodata registration devices must be used to record traffic conditions;

- based on the received data, it is necessary to create a data bank that will be processed in the laboratory;

- based on indicators of the drivers' functional state, it is necessary to establish the corresponding graphic and mathematical dependencies.

The research was conducted on the route Lviv Uzhhorod. Altitude values of the road, which runs the studied route (Fig. 4), were obtained using the online resource "Altitude Maps" [19].

The division of the bus route sections into "mountain" and "plain" traffic conditions was carried out according to the data given in [14], in particular:

- placement height up to $600 \mathrm{~m}$. above sea level, tortuosity index up to 0.55 (plain conditions);

- placement height over $600 \mathrm{~m}$. above sea level, tortuosity index greater than 0.55 (mountainous conditions) 


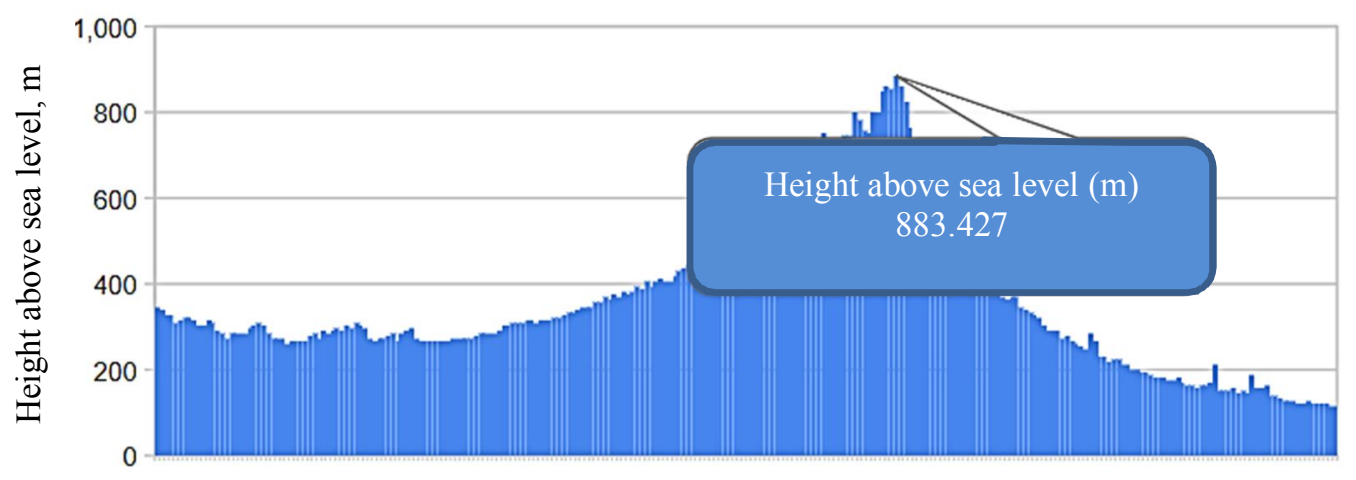

Fig. 4. Altitude values of the road's position through which the studied route runs

According to the above, approximately $20 \%$ of the route runs in mountainous traffic conditions. Thus, the general indicators of a route on which buses' drivers' functional state was researched are shown in Table 1.

Table 1

General indicators of the bus route on which researches were done

\begin{tabular}{|c|c|c|c|}
\hline \multirow{2}{*}{$\mathrm{N}$} & \multirow{2}{*}{ Name of indicators } & \multicolumn{2}{|c|}{ Quantitative indicators of the direction } \\
\hline & & forward & reverse \\
\hline 1 & Length of the route, $\mathrm{km}$ & 247 & 247 \\
\hline 2 & Movement duration, hours, minutes & 290 & 290 \\
\hline 3 & Stops, number & 27 & 27 \\
\hline 4 & Bus stations, number & 2 & 2 \\
\hline 5 & Dispatching and control points & Available & Available \\
\hline 6 & $\begin{array}{l}\text { Availability of equipped platforms for reversal } \\
\text { of buses at the endpoints of the route }\end{array}$ & Yes & Yes \\
\hline
\end{tabular}

Buses BAZ A079.24 run on the studied route. These vehicles were equipped with a Garmin Dash Cam 45 device that recorded instant speeds and video in different driving conditions. In this case, the video, which was processed in the laboratory, provided data on date, coordinates, time, speed, and geolocation. All this information was stored on a microSD memory card.

The study of HRV indicators required to calculate the indicator of regulatory systems' activity of drivers was carried out using the above-mentioned portable device Polar H7 and CardioMood HRV lite software. At the same time, the established data was distributed during the bus movement in the forward and reverse directions of the traffic route. The calculation of the indicator of regulatory systems' activity value of drivers who drove a bus on the studied route was carried out according to formula (1). The software environment Microsoft Excel was used to systematize the obtained values and create appropriate graphical (Fig. 5 and Fig. 6) and mathematical dependencies.

After analyzing the values of elevations (Fig. 4) and video recording data, the range of values of the drivers 'indicator of regulatory systems' activity was established:

According to the results of research, a mathematical model of changes in the functional state of bus drivers was obtained:

- the forward direction of the traffic route:

$$
P_{F}=-9 \cdot 10^{-5} \cdot t^{2}+0,0458 \cdot t+P_{I}-0,8113,
$$

where $P_{F}$ - the final value of the indicator of driver's regulatory systems' activity, points; $t$ - duration of movement, $\min$.; $P_{I}-$ the initial value of the indicator of driver's regulatory systems' activity, points.

- the reverse direction of the route:

$$
P_{F}=-2 \cdot 10^{-6} \cdot t^{3}-0,008 \cdot t^{2}+0,1028 \cdot t+P_{I}+1,1054 .
$$




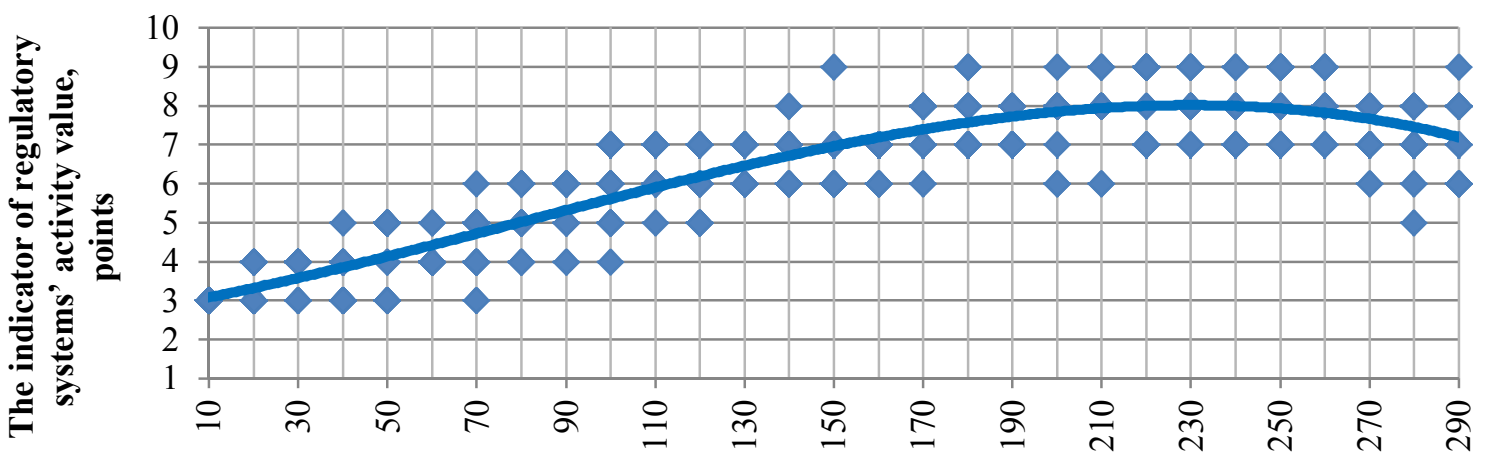

Duration of movement, min.

Fig. 5. Dynamic of the drivers 'functional state change who drove the bus on the route in the forward direction

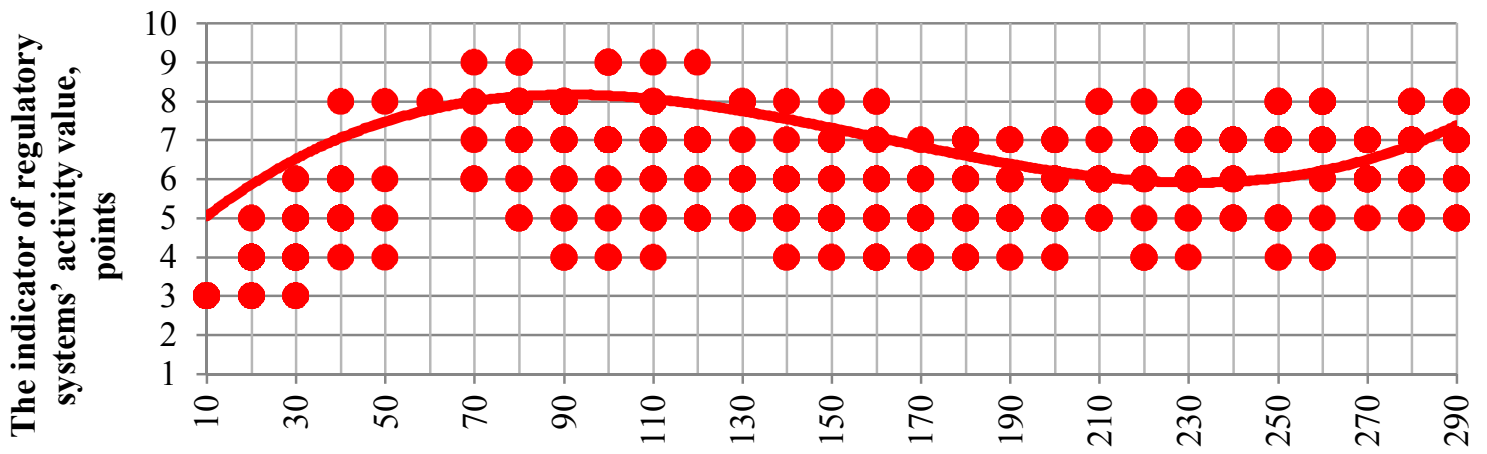

Duration of movement, min.

Fig. 6. Dynamic of the drivers 'functional state change who drove the bus on the route in the reverse direction

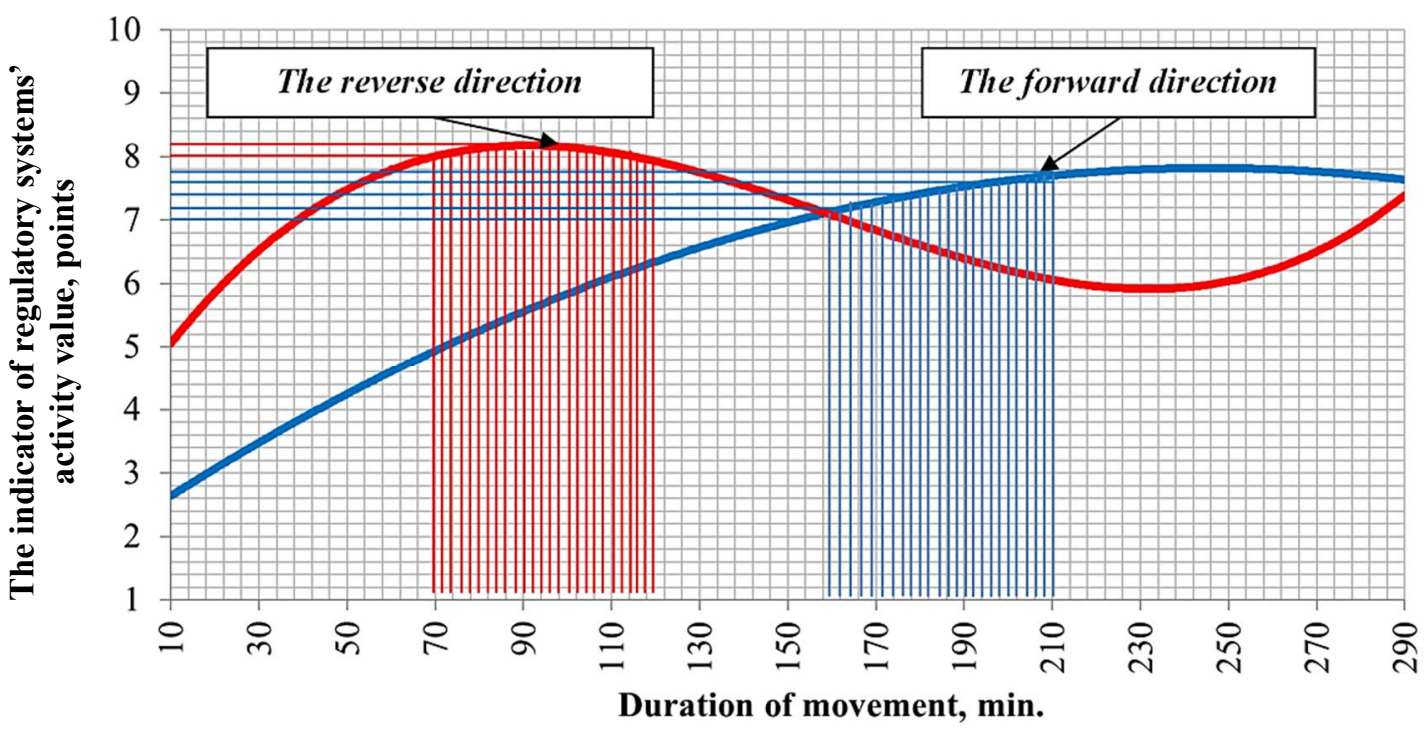

Fig. 7. Determination of the influence of mountainous traffic conditions on the value of bus driver 's functional state

Thus, on average, the following traffic conditions were observed at:

- in the forward direction from 160 minutes. up to 210 minutes;

- in the reverse direction from 70 minutes. up to 120 minutes 
Thus, it was found that in the forward and reverse directions in mountainous traffic conditions, the value of the indicator of regulatory systems' activity of drivers can reach the value of 7-8 points, which corresponds to the state of overload of regulatory systems. In this state of the driver, the reliability of his work is reduced, and his body is not fully able to adequately respond to external factors. It should be noted that in the reverse direction at the beginning, the driver's indicator of regulatory systems' activity increases rapidly due to the entry of his body into working conditions and adaptation to mountainous traffic conditions.

\section{CONCLUSIONS}

1. The study of the mountainous traffic conditions' influences on the bus drivers` functional state is carried out. At the same time, during the measurements, the research conditions were taken into account, in particular, the height position of the road on which the bus was moving, the radiuses of the road plan, etc. Also, one of the preparation stages for the study was the main existing methods' analysis of collecting the roads`characteristics and indicators of the drivers` functional state.

2. The researches of transport streams parameters with the use of photo and video equipment are carried out. The obtained values were analyzed in the laboratory. The intensity and composition of the traffic flow, the duration of the bus movement, the altitude values of the road's position, etc., were established. Also, using the Polar H7 and the CardioMood HRV lite software, HRV indicators were determined. These made it possible to calculate the value of the indicator of regulatory systems 'activity of drivers during their work. This indicator ranged from 2 to 9 points.

3. According to the established data, the values of the reliability of the approximation $\mathrm{R}^{2}$ are determined. Its values range from 0.78 to 0.85 units. Mathematical and graphical dependencies are also identified, which reflect the dynamics of changes in the indicator of regulatory systems' activity of bus drivers while driving in the plains and mountains. Mountainous traffic conditions were observed in the range of 160 minutes up to 210 minutes in the forward direction and from 70 minutes up to 120 minutes in the reverse direction. It was established that such traffic conditions significantly affect the dynamics of the driver's indicator of regulatory systems' activity, which can change by 1.3-1.7 times. Following the above, it is necessary to create schedules of the drivers' work and rest, considering the special conditions in which the vehicle will move and the driver will work.

\section{References}

1. Pegin, P., \& Pegina, O. (2018). A method to assess accident psychological severity in drivers. Transportation research procedia, Volume 36, 562-566. doi: 10.1016/j.trpro.2018.12.152 (in English)

2. Dolia, V. \& Englezi, I. (2015). Determine the safe transport of dangerous goods route. Journal of Transport Problems", Volume 10. 31-44. doi: 10.21307/tp-2015-004 (in English)

3. Chen, J., Wang, H., Hua, C., Wang, Q., \& Liu, C. (2018). Graph analysis of functional brain network topology using minimum spanning tree in driver drowsiness. Cognitive neurodynamics, 12(6), 569-581. doi: 10.1007/s11571-018-9495-z (in English).

4. Maria, Rosaria De Blasiis, Selene Diana \& Valerio, Veraldi (2018). Safety audit for weaving maneuver: A driver simulation safety analysis. Journal of Transportation Safety \& Security, Volume 10. Issue 1-2. 159-175. doi: 10.1080/19439962.2017.1323060 (in English)

5. Prasolenko, O. (2019). Teoretychni osnovy ta praktychni metody vyznachennia nadiinosti diialnosti vodiia $\mathrm{v}$ mistakh u temnu poru doby [Theoretical frameworks and practical methods for determination of driver's reliability in cities at night]. Problemy z transportnymy potokamy i napriamy yikh rozviazannia: tezy dopovidei III Vseukrainskoi naukovo-teoretychnoi konferentsii [Problems with traffic flows and directions of their solution: abstracts of reports of the III All-Ukrainian scientific-theoretical conference] (pp. 129-132). (in Ukrainian)

6. Kantowitz, B. H., Hanowski R. J., \& Kantowitz S. C. (2020). Driver reliability requirements for traffic advisory information. Ergonomics and safety of intelligent driver interfaces (pp. 1-22). doi: 10.1201/9781003064107 (in English)

7. Buendia, R., Forcolin, F., Karlsson, J., Arne Sjöqvist, B., Anund, A., \& Candefjord, S. (2019). Deriving heart rate variability indices from cardiac monitoring - An indicator of driver sleepiness. Traffic injury prevention, Volume 20(3), 249-254. doi: 10.1080/15389588.2018.1548766 (in English) 
8. Hiuliev, N., Lobashov, O., Shkabara, O., \& Doroshenko, A. (2018). Shchodo vplyvu temperamentu vodiia na chas yoho reaktsii u dorozhnomu zatori [Regarding the influence of the driver's temperament on the time of his reaction in traffic jams]. Komunalne hospodarstvo mist. [Municipal economy of cities], Volume 140, 86-90. (in Ukrainian)

9. Gorelik, S., Grudinin, V., Lecshinskiy, V., \& Khaskelberg, E. (2020). Method for assessing the influence of psychophysical state of drivers on control safety based on monitoring of vehicle movement parameters. Transportation research procedia, Volume 50, 152-159. doi: 10.1016/j.trpro.2020.10.019 (in English)

10. Studer, L., Paglino, V., Gandini, P., Stelitano, A., Triboli, U., Gallo, F., \& Andreoni, G. (2018). Analysis of the relationship between road accidents and psychophysical state of drivers through wearable devices. Applied Sciences, Volume 8(8), 1230. doi: 10.3390/app8081230 (in English)

11. Lin, Wang, Hong, Wang, \& Xin, Jiang. (2017). A new method to detect driver fatigue based on EMG and ECG collected by portable non-contact sensors. Promet - Traffic\&Transportation, Volume 29, 479-488. doi: 10.7307/ptt.v29i5.2244 (in English)

12. Murugan, S., Selvaraj, J., \& Sahayadhas, A. (2020). Detection and analysis: driver state with electrocardiogram (ECG). Physical and engineering sciences in medicine, Volume 43(2), 525-537. doi: 10.1007/s13246-020-00853-8 (in English)

13. Lisun, Yu. B., \& Uhlev, Ye. I. (2020). Variabelnist sertsevoho rytmu, vykorystannia ta metody analizu [Heart rate variability, use and methods of analysis]. Pain, anaesthesia \& intensive care, Volume 4 (93), 83-89. doi: 10.25284/2519-2078.4(93).2020.220693 (in Ukrainian)

14. Afonin, M. O. (2019). Vdoskonalennia tekhnolohichnykh protsesiv perevezennia nebezpechnykh vantazhiv z vrakhuvanniam faktora liudyny [The improvement of technological processes of dangerous goods transportation considering human factor]. Candidate's thesis. Lviv: LPNU (in Ukrainian).

15. Barvinska, K., \& Hrutsyn, O. (2020). Doslidzhennia zatrymky transportnoho potokuna nerehulovanykh perekhrestiakh z obmezhenoiu shvydkistiu [Investigation of transport flow delay at unsignalized intersections with limited speed]. Rozvytok transportu [Transport development], Volume 1 (6), 80-91. doi: 10.33082/td.2020.1-6.07 (in Ukrainian)

16. Lobashov, O. O., \& Prasolenko, O. V. (2018). Vplyv kharakterystyk dorozhnoho rukhu na funktsionalnyi stan vodiia [Influence of traffic characteristics on the functional state of the driver]. Komunalne hospodarstvo mist. [Municipal economy of cities], Volume 7, 40-45. doi: 10.33042/2522-1809-2018-7-146-40-45 (in Ukrainian)

17. Gyulyev, N., \& Dolia, C. (2017). The issue of probability of traffic road accident on the elements of the transport network. American Journal of Social Science Research, Volume 3(5), 17-24. (in English)

18. Furman, O. (2017). Hardware and software for road users functional state research. In Litteris et Artibus (pp. 287-288). (in English)

19. Karty vysoty [Altitude maps]. Retrieved from https://qrz.pp.ua/vysota (in Ukrainian).

Received 17.08.2021; Accepted in revised form 27.09.2021.

\section{ВПЛИВ ГІРСЬКИХ УМОВ РУХУ НА ФУНКЦІОНАЛЬНИЙ СТАН ВОДІЯ АВТОБУСА}

Анотація. Забезпечення транспортного прочесу потребує належної взаємодії всіх ланок системи "водій автомобіль - дорога - середовище” та ї̈ підсистем. У иььому випадку водій часто виступає “слабкою” складовою системи, а його дї можуть призводити до зниження рівня безпеки учасників дорожнього руху. Треба зазначити, надійність роботи водія можуть розглядати як ймовірність його безвідмовного та безпомилкової роботи, а також як належний рівень функиіонування його регуляторних механізмів. Часто, в такому разі, для аналізу діяльності та готовності водія до професійної иого діяльності, використовують показники функціонального стану. Таким чином, дослідження людини-оператора у транспортному прочесі є важливим завданням щодо забезпечення надійності функціонування транспортної системи загалом. 
Сьогодні левова частка всіх перевезень як у межах населеного пункту, так $і$ за межами, здійснюється саме автомобільним транспортом. Від дій водія залежить своєчасність та збереженість доставки вантажів та безпека пасажирів. Під час роботи на водія впливає значна кількість чинників впливу зовнішнього середовища. Одним з найвагоміших $\epsilon$ умови руху в гірській місиевості, в якій часто спостерігається значна кількість кривих як у плані, так і в профілі автомобільних доріг. Ще одною особливістю таких умов руху є висотне положення над рівнем моря, яке також впливає на організм людини, зокрема на ії функиіональний стан.

Враховуючи вищезазначене, у роботі здійснено заміри показників варіабельності сериевого ритму водіїв автобусів, які рухалися на маршруті, що частково пролягав у гірській місиевості. Під час натурних досліджень також здійснювалася відеофіксаиія та реєстрачія геоположення транспортного засобу. Це дало змогу встановити показники функиіонального стану водія у конкретний досліджуваний період. Після опрацюввання отриманих значень встановлено вплив гірських умов руху на значення показника активності регуляторних систем водїв автобусів.

Ключові слова: функиіональний стан, водій, автобус, гірські умови руху, безпека руху, надійність роботи водія, показник активності регуляторних систем. 